\title{
Possible influence of the ENSO phenomenon on the pathoecology of diphyllobothriasis and anisakiasis in ancient Chinchorro populations
}

\author{
Bernardo T Arriaza ${ }^{1}{ }^{+}$, Karl J Reinhard ${ }^{2}$, Adauto G Araújo ${ }^{3}$, Nancy C Orellana ${ }^{4}$, Vivien G Standen ${ }^{5}$ \\ ${ }^{1}$ Instituto de Alta Investigación, Departamento de Antropología, Centro de Investigación del Hombre en el Desierto ${ }^{4}$ Convenio de \\ Desempeño, UTA-MINEDUC ${ }^{5}$ Departamento de Antropología, Universidad de Tarapacá, Arica, Chile ${ }^{2}$ School of Natural Resources, \\ University of Nebraska, Lincoln, USA ${ }^{3}$ Escola Nacional de Saúde Pública-Fiocruz, Rio de Janeiro, RJ, Brasil
}

Current clinical data show a clear relationship between the zoonosis rates of Diphyllobothrium pacificum and Anisakis caused by the El Niño Southern Oscillations (ENSO) phenomenon along the Chilean coast. These parasites are endemic to the region and have a specific habitat distribution. D. pacificum prefers the warmer waters in the northern coast, while Anisakis prefers the colder waters of Southern Chile. The ENSO phenomenon causes a drastic inversion in the seawater temperatures in this region, modifying both the cool nutrient-rich seawater and the local ecology. This causes a latitudinal shift in marine parasite distribution and prevalence, as well as drastic environmental changes. The abundance of human mummies and archaeological coastal sites in the Atacama Desert provides an excellent model to test the ENSO impact on antiquity. We review the clinical and archaeological literature debating to what extent these parasites affected the health of the Chinchorros, the earliest settlers of this region. We hypothesise the Chinchorro and their descendants were affected by this natural and cyclical ENSO phenomenon and should therefore present fluctuating rates of D. pacificum and Anisakis infestations.

Key words: ENSO - climate changes - paleoepidemiology - Diphyllobothrium - Anisakis - Chinchorro mummies

The ecology of the Atacama Desert, where the Chinchorro people settled nearly 9,000 years ago, is apparently affected by cyclical environmental variations that have significant impacts on the marine biota and human health (Madl 2000, Kruse et al. 2004, Santoro et al. 2005). These alterations in the temperature of the ocean currents, a phenomenon named ENSO (El Niño-Southern Oscillations), come from fluctuations in global weather patterns. The weakening of the easterly trade winds allows the warmer equatorial waters of the western Pacific to move east toward the South American coast. Ocean currents alternate between warm (El Niño) and cold events (La Niña) every 3-7 years (Fontugne et al. 1999, Madl 2000). Warm tropical waters around late December periodically alter the cold Humboldt Current along the South American coast. This oceanic current collision causes drastic changes in the coastal water temperatures modifying the cool nutrient-rich seawater that is normally found along the coast of Ecuador, Peru and Chile (Fontugne et al. 1999, Sagua et al. 2001, Cabrera \& Trillo 2004).

ENSO phenomenon has been suggested to increase the prevalence of parasitic infections by bringing new sylvatic mammals to the region, such as fish and birds adapted to warm currents. Some research groups have argued that this warmer environmental change correlates

Financial support: Convenio de Desempeño UTA-MINEDUC, FONDECYT Chile (1070575)

+ Corresponding author: barriazaarica@gmail.com

Received 3 July 2009

Accepted 27 August 2009 positively with the increases in the incidence of Diphyllobothrium pacificum human infections that were observed in Northern Chile during the 1975-2000 El Niño events (Madl 2000, Sagua et al. 2001). In Chile, four food-borne helminthic zoonoses are associated with the consumption of raw, smoked or undercooked fish. Two of those infections are caused by the cestodes Diphyllobothrium latum and D. pacificum. The remaining two are produced by the nematodes Anisakis simplex and Pseudoterranova decipiens (Myers 1976, Sagua et al. 2001).

In their natural life cycles, the patterns of parasite distribution along the Pacific coast of Chile are defined by changes in their prey-items, which are intermediate hosts along their distributional latitudinal range and through El Niño events (González \& Poulin 2005). It is noteworthy that these cold and warmer water and biota oscillations have fascinating evolutionary implications. We have the ability to ask how far back in time the Andean populations were affected by this climatic phenomenon. We can also examine how parasite frequency shifted according to water temperature oscillations. We propose that the local Chinchorro populations, the earliest settlers of Northern Chile (9000 BP), that relied on hunting-gathering and fishing subsistence strategies were significantly affected by the ENSO phenomenon, thus experiencing a shift in their parasitic load over time. In other words, their parasitic load of infections, including diphyllobothriasis and anisakiasis, varied according to the ENSO fluctuations and intensities.

The natural history of Diphyllobothrium - There are approximately 80 species of Diphyllobothrium and three of these species have been identified in modern human populations residing in South America. This list includes D. latum, D. pacificum and Diphyllobo- 
thrium dendriticum (Atias \& Cattan 1976). Diphyllothriasis is a zoonosis that is transmitted by the ingestion of plerocercoid larvae from the Diphylobothrium genera in raw meat. Plerocercoids are frequently encountered in the muscle of freshwater and marine fish (Chai et al. 2005).

Human diphyllobothriasis is widespread and has been reported in Europe, Asia, North America and in South America (Oshima 1972, Sagua et al. 2001, Dupouy \& Peduzzi 2004). The Diphyllobothrium species (tapeworm) are endemic in several regions of the world. Of these species, D. latum is the most common in human cases (Lal \& Steinhart 2007), particularly in Europe. Some D. latum cases identified in Peru and Brazil were later identified as D. pacificum, a parasite of seals, sea lions and other marine mammals (Baer 1969, Cattan et al. 1977). In South America, only Chile and Argentina have reported autochthonous human cases of diphyllobothriasis caused by D. latum (Semenas et al. 2001). The $D$. latum and $D$. dendriticum parasite species were not originally from South America and were originally introduced to the continent by European immigrants (Semenas \& Úbeda 1997).

Species identification within this parasitic genus is relevant because $D$. pacificum infects only saltwater fish (Sagua et al. 2001). In contrast, D. latum and D. dendriticum develop their life cycle in freshwater. The Diphyllobothrium life cycle involves many developmental stages. First, under appropriate conditions, parasite eggs mature and develop into a coracidia, which are ingested by crustaceans. The coracidia stage next develops into procercoid larvae. Following ingestion of the crustacean by a fish, the second intermediate host, the procercoid larvae, migrates into the flesh of the fish, where they develop into a vermiform plerocercoid larva. The second intermediate hosts (i.e., the fish) can then be eaten by a larger predator fish or marine mammal species. The plerocercoid larvae are the infective stage for both humans and other mammals and are acquired by eating raw or undercooked meat that has been infected. After ingestion of the infected fish, some plerocercoids develop into mature adult tapeworms, which will reside in the small intestine of the host (Janicki 1917, Meyer 1970). Sea lions and other carnivorous mammals (such as humans, dogs, cats, bears, otters and the like) are definitive and well characterised hosts of Diphyllobothrium species (Meyer 1970, Cabrera et al. 2001).

Most persons are asymptomatic after their initial infection with the parasite, although diphyllobothriasis occasionally produces a variety of gastrointestinal disorders, including abdominal distention, flatulence, intermittent abdominal cramping and diarrhoea (Baer 1969). The $D$. pacificum tapeworm can grow to several meters in the lower intestine, competing with the host for nutrients, particularly vitamin B12. This nutrient depletion may eventually cause severe anaemia (Von Bonsdorff 1977).

Reports of Diphyllobothrium in the current Chilean and Peruvian populations are not unusual. In 1976, the first cases of human infections were documented in Chile (Atias \& Cattan 1976). More recently, several clinical cases of D. pacificum were identified and re- ported in adults and children from Antofagasta (Sagua et al. 2001). All had ingested raw fish (ceviche) prepared with Sciaena deliciosa (corvina) and Seriolella violacea (cojinova). It is clear that most of the current Chilean cases of D. pacificum have occurred in coastal cities such as Arica, Iquique, Tocopilla, Mejillones, Antofagasta, los Vilos and Puerto Montt. All cases were associated with reported El Niño events and the predominance of cases was shown to be concentrated in the northern cities of Chile (Sagua et al. 2001). D. latum cases were reported in Chile and the parasites measured between 2.9-11 m. The infections were traced to lake areas from the Southern Chilean Region, where infection by plerocercoids in salmonids is very frequent due to the consumption of ceviche (Cabello 2007).

The natural history of Anisakis - Anisakiasis is a human disease caused by the ingestion of larval nematodes belonging to the Anisakidae family. Infections are acquired by the ingestion of raw seafood (Torres et al. 2000). There are three types of Anisakis larvae that have been implicated in human disease: the Anisakis (sensu lato), Pseudoterranova (Phocanema) (sensu lato) and Contracaecum (sensu lato) species. These parasites are highly abundant in cold seawater. Anisakiasis has been reported in The Netherlands, Japan, Germany, Switzerland, France, the United Kingdom, Belgium, New Zealand, Chile, Peru and North America (Oshima 1972).

Anisakis has a life cycle involving three hosts: sea mammals, crustaceans and fish. Adult worms can be found in the stomachs of dolphins, sea lions (including Otaria) and whales. Female worms lay eggs that then exit the body in the faeces of the marine mammals, where they then embryonate in the seawater. Small crustaceans such as krill subsequently consume second-stage larvae that hatch out. This infected first intermediate host is then eaten by marine fish and squid, in which the thirdstage larvae encyst. The life cycle is finally completed when the marine mammals eat these infected fish or squid (Sakanari \& Mckerrow 1989). The crustacean host could theoretically infect the marine mammals, in which case fish and squid would act only as transport hosts. While plausible, this mode of infection has not been documented. Infection can lead to the development of ulcers in infected humans and sea mammals, although human infection is accidental (Cattan et al. 1976).

Several fish species are implicated in Anisakis transmission around the world. The presence of the following nematodes was reported in Chile (21): A. simplex (As), P. decipiens ( $\mathrm{Pd})$ and Hysterothylacium sp., in fresh marine fish at a commercial market located in Valdivia. The infected fish species included Chilean hake, Merluccius gayi (As; Pd); the tail-hake, Macrouronus magellanicus (Pd; $\mathrm{H}$ sp.); the red-conger-eel, Genypterus chilensis (Pd); the flatfish, Paralichthys microps (As, Pd); and the Chilean mackerel, Trachurus murphyi (As, Pd).

The parasite has also been reported in Antofagasta (González \& Poulin 2005) from fish caught between 2003-2004. The researchers pointed out that in the natural coastal environment the parasite diversity in fish depended on the number of crustaceans that were pres- 
ent as intermediate hosts and the ecology of the region. These authors also suggested that endoparasite species richness correlated well with latitude, with increasing levels towards the south of Chile (Fig. 1).

The pathology resulting from Anisakis infection ranges from minor to severe symptoms (Sakanari \& Mckerrow 1989). Sometimes the infected patient coughs up the Anisakis larvae. Patients suffer from symptoms of expectoration, pharyngeal pain, nausea and anal or nasal pruritus. Extreme gastric pain is also caused when the worms burrow into the lining of the stomach. This can occur just hours after eating the infected raw fish (Noh et al. 2003). More severe problems might occur in the form of bowel obstructions and surgery is sometimes necessary to treat and remove the worms from infected organs (Yoon et al. 2004).

Human infection with D. pacificum and Anisakis is peripheral to the normal parasite ecology of fish intermediate host species. Humans infected with $D . p a-$ cificum will be effective hosts because the worms can mature in human intestinal tracts. However, humans are an accidental dead-end host for anisakids because the worms cannot reach sexual maturity. The human morphology and physiology is therefore inhospitable for the completion of the Anisakis sexual cycle.

Current data clearly show that global weather changes caused by ENSO affect parasite pathoecology (Sagua et al. 2001). Figs 1 and 2 illustrate that Anisakis displays a preference for colder waters, the frequencies are thus higher in southern latitudes $\left(39-53^{\circ}\right)$, reaching a parasite prevalence of $86.5 \%$ (González \& Poulin 2005). Using these previously generated data (parasite frequency versus latitude) we calculated a correlation coefficient (Pearson) of 0.86 . Thus, this value is a high-quality indicator for the prediction of parasite frequencies along the Pacific South American coast. During the La Niña event, colder waters move upwards along the Northern Chilean coast increasing the typically low prevalence of Anisakis in higher latitudes (Figs 1,2). In contrast, during the El Niño event, warmer waters became more typical, therefore increasing $D$. pacificum prevalence in southern latitudes that normally show lower overall levels (Gonzalez et al. 1999, Sagua et al. 2001). In others words, the model will predict that a fluctuating prevalence of D. pacificum and Anisakis infestations along the South American Pacific coast should be observed during the natural and cyclical ENSO phenomenon.

Archaeological evidence of ENSO - Paleoclimatic data demonstrate climate variations in the Andean region during the Holocene period (Sandweiss et al. 2001). The Laguna Lejía, near San Pedro, in the Atacama desert shows that during the late glacial period i.e., 13,500-11,500 years ago, water resources were more abundant than today (Grosjean 1994). In Northern Chile, a humid period started 13,000-12,000 years ago and ended about 8,000 years ago when the paleolakes disappeared (Geyh et al. 1999).

The analysis of diatoms revealed that Lake Titicaca dropped its water level by approximately $100 \mathrm{~m}$ about 5,500 years ago (Tapia et al. 2003). In the mid-Holocene,

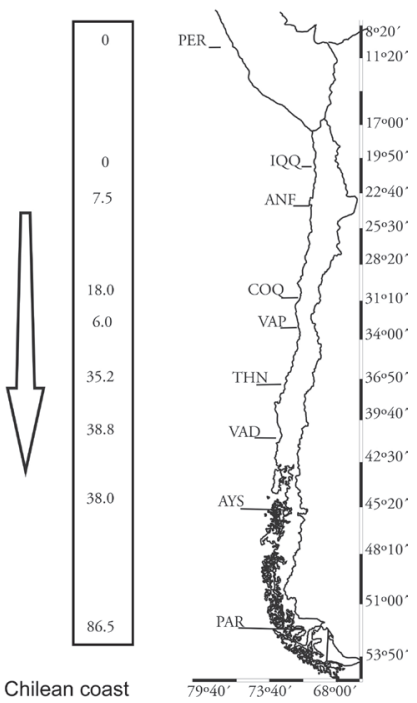

Fig. 1: Anisakis parasite prevalence according to latitude along the Chilean coast during April-September 2003 and April-August 2004. ANF: Antofagasta $\left(24^{\circ} \mathrm{S}\right)$; AYS: Aysén channels $\left(45^{\circ} \mathrm{S}\right)$; COQ: Coquimbo $\left(30^{\circ} \mathrm{S}\right)$; IQQ: Iquique $\left(20^{\circ} \mathrm{S}\right)$; PAR: Punta Arenas $\left(52^{\circ} \mathrm{S}\right)$; PER: Huacho $\left(11^{\circ} \mathrm{S}\right)$; THN: Talcahuano $\left(36^{\circ} \mathrm{S}\right)$; VAL: Valparaíso $\left(33^{\circ} \mathrm{S}\right)$; VALD: Valdivia $\left(40^{\circ} \mathrm{S}\right)$. Modified from González \& Poulin (2005).

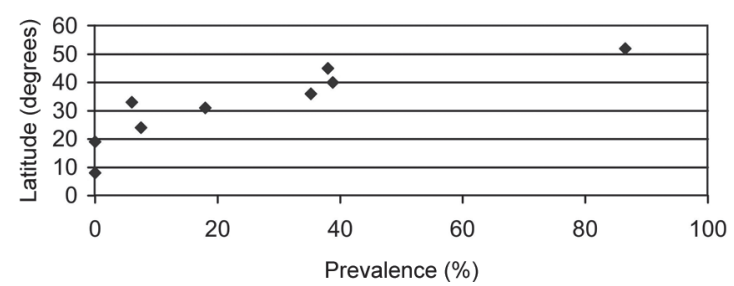

Fig. 2: Anisakis prevalence by latitude in Sebastis capensis. Data taken from González \& Poulin (2005).

the climate of the Atacama Desert was punctuated with dry and wet periods, forcing people to migrate to the coast as terrestrial resources diminished in the Andes. Thus, the Chinchorro coastal occupation of Northern Chile coincides with an extremely arid period in the highlands.

Preceramic coastal hunter-gatherer populations must have been significantly affected by coastal microenvironment change. At the site of Quebrada de los Burros Tacna, Peru, an El Niño event dated at approximately 9,000-3,400 years ago left 14 organic layers, revealing increasing condensation of fog at the coast and an increasing water supply (Fontugne et al. 1999). The ENSO phenomenon led to variations in the availability of food resources in both the coastal and highland environments. Highland rain increases during the El Niño phenomenon brought more water down the hills. However, these resources must have varied significantly. Even today, the local rivers of Northern Chile are dry for most of the year, except during the months of January and February. This arid condition for the majority of the year significantly affects the biota of the region. Thus, we believe 
that the Chinchorro gathering and collecting strategies were subjected to the ENSO fluctuations that, in turn, affected their parasitic load.

Paleoparasitological evidence - Evidence of prehistoric infection with fish tapeworms and roundworms comes from two sources: one is the discovery of direct evidence of the fish tapeworm in the intestines of mummies and the other source is evidence of fish roundworm infections as indirect indications from zooarchaeology. The data provided from paleoparasitology and coprolite studies from Huaca Prieta, Peru, dated to $\sim 450$ BP, revealed the presence of Diphyllobothrium eggs and suggest that ancient hunter-gatherer populations were infected by D. pacificum (Callen \& Cameron 1960). More evidence of prehistoric diphyllobothriasis from South America was later discovered. Patruco et al. (1983) found eggs in one of 52 coprolites from the coastal site of Los Gavilanes, which is located in North-central Peru. These samples were later dated to $4800 \mathrm{BP}$. In addition, $D$. $p a$ cificum eggs in Chile were reported in four of 26 human coprolites from Tiliviche village (40 km inland), dating to $6060-3900$ BP (Ferreira et al. 1984). These findings demonstrate that either trade with infected fish reached inland, that inland people migrated to the coast to obtain marine resources, or both (Reinhard \& Aufderheide 1990). The chronological age of these findings is in synchrony with the El Niño events reported for Quebrada Los Burros (Fontugne et al. 1999). D. pacificum infection was also found to be endemic in later coastal and inland Chiribaya populations of the Moquegua River valley in Southern Peru (Martinson et al. 2003). Diphyllobothrium sp. eggs were also found in seven of 29 coprolites examined from four Chiribayan archaeological sites in Southern Peru (700-1476 AD) (Holiday et al. 2003).

Reinhard \& Urban (2003) also reported evidence of D. pacificum in Chilean coastal mummies. Sixteen naturally preserved mummies were examined from the cemetery of Morro 1-6. Of these samples, five were positive for D. pacificum eggs (cases: MO1-6 T-55; MO1-6 T-U1; MO1-6 T-18; MO1-6 T-U7 and MO1-6 T-10). In contrast, none of eight mummies from the site of Morro 1 were positive for $D$. pacificum eggs. The difference between the two sites is therefore noteworthy. Parasitological analysis of the Morro 1-6 cemetery shows eggs that were abnormally small, where this could be explained by the probable low nutrient availability for the parasite in seawater, likely caused by an ENSO phenomenon during that time. Morro 1-6 dates range from about 4350-3550 BP and Morro 1 from about 4950-3750 BP. These two sites are only a few meters from each other. Reinhard and Urban (2003) suggested the small size is because these eggs were immature within the segments of the parental worms. As the proglottids of the worms decomposed, the small, immature eggs were released into the mummifying intestinal tract. These authors suggested that the immature eggs never reached an infective stage.

In summary, human D. pacificum infections in Peru and Chile began about 6000 BP or earlier and the infections varied regionally. Their cyclic appearance is probably associated with the ENSO phenomenon.
Other paleoparasitological data from studies has yielded results of human intestinal paleoparasites. Shell midden sediments from Canada's Pacific coast showed evidence of the fish tapeworm, Diphyllobothrium spp (Bathurst 2004). The presence of D. pacificum was also reported in sediment from a pre-Columbian burial and in the remains of a child from the Aleutian Islands of Alaska. There is also a more recent report associating the marine diet of the population with the acquisition of pre-Columbian infection (West et al. 2003).

Diphyllobothrium spp eggs were also found in archaeological material, dated to the Neolithic times in Switzerland (Dommelier 2001). In Germany and France, the parasite was found in sites dating to the Middle Ages and Gallo-Roman periods (Jansen et al. 1962, Bouchet et al. 2001, 2003).

Zoo archaeological evidence associated with parasite transmission - Zooarchaeologists have identified seven fish species in Chinchorro shell middens (Table). With the exception of Pimelotopon, all of these fish are hosts to one or more species of the Anisakidae family in Southern Chile (Torres et al. 2000). At a minimum, $A$. simplex is endemic to Northern Chile, such that Chinchorro populations were at risk of getting this infection by consumption of these fish.

In view of the archaeological evidence regarding fishing for food, Chinchorro people might have experienced anisakiasis and diphylobrothiasis infections by the oral transmission route. Zooarchaeology has provided indirect evidence of potential infections by different parasites, revealing the distribution through time of intermediate fish host eaten by the Chinchorros (Llagostera 1992, Reinhard \& Urban 2003)

Anisakid parasites have not been reported in archaeological studies. This could be because of the lack of research focused on this parasite or because it was eliminated by humans, who precluded further parasitologic observations. Human infection by Anisakis is accidental and humans are not suitable hosts for these parasites (Sakanari \& Mckerrow 1989). No multiplication of the parasite occurs in humans and no reproductively mature anisakids nematodes have been reported from human infections. Larvae in the intestinal lumen cause no symptoms, but severe cases of anisakiasis occur when larvae penetrate the intestinal wall. However, in D. pacificum infection, humans are effective hosts because the worms can mature in the human intestinal tracts.

Discussion and bioarchaeological implications The population of the Atacama coast by humans began around 13000-12000 BP. Later, around $7000 \mathrm{BP}$, in the Arica-Camarones area, Chinchorro people developed artificial mummification, thus transforming their dead into highly artistic mortuary icons. This is quite intriguing, considering that they were hunter-gatherer-fishing populations (Arriaza \& Standen 2009).

The Chinchorro diet has been reconstructed using bone chemistry (Aufderheide \& Allison 1992) and coprolite samples, revealing the consumption of a variety of maritime foods (Reinhard \& Aufderheide 1990). The biocultural debris or shellmiddens left behind by the 
TABLE

Fish species found in Chinchorro occupational archaeological sites (Schiappacase \& Niemeyer 1984) and Anisakis parasites reported in modern fish (Torres et al. 2000)

\begin{tabular}{|c|c|c|c|}
\hline Type of fish & Common Chilean name & English name & Host to \\
\hline Sarda chilensis & Bonito & $\begin{array}{l}\text { Tunny } \\
\text { (Tuna) }\end{array}$ & Anisakis physeteris \\
\hline Trachurus murphyi & Jurel & Black jack & $\begin{array}{c}\text { Pseudoterranova decipiens } \\
\text { Anisakis simplex } \\
\text { A. physeteris }\end{array}$ \\
\hline Mugil cephalus peruanus & Lisa & Grey mullet & $\begin{array}{l}\text { P. decipiens } \\
\text { A. simplex }\end{array}$ \\
\hline Scomber japonicus peruanus & La caballa & Mackerel & $\begin{array}{l}\text { A. physeteris } \\
P . \text { decipiens }\end{array}$ \\
\hline Paralichtys sp. & Lenguado & Sole & $\begin{array}{l}\text { P. decipiens } \\
\text { A. simplex }\end{array}$ \\
\hline Cilus monti & Corvina & Croaker & P. decipiens in related species \\
\hline
\end{tabular}

Chinchorros, for example in Caleta Quiani, Quebrada de Camarones and Pisagua Viejo, revealed a mixed maritime fishing-gathering-hunting and riverine subsistence. The shell midden showed a presence of otholits, revealing that they definitely sought low and medium deep-water fish. In addition, data from cemeteries and middens has showed that they hunted marine mammals (e.g., sea lions). This evidence suggests that these animals were likely very abundant in the region and certainly part of the parasite cycle (Arriaza \& Standen 2009). Chinchorros did not have watercraft, thus they had to hunt animals in their immediate environment.

Not only was the type of consumed food a parasite transmission factor, but also cooking techniques. Wood was and remains, scarce at the coast and the Chinchorro consequently used dried totora (Typha angustifiola) and junquillo (Scirpus sp.) as fuel. Thus, eating raw or partially cooked fish meat, increased parasite risk transmission. The data from Peruvian and Chilean ancient sites show that preceramic populations were affected by $D$. pacificum, implying warmer water associated to the cyclical ENSO phenomenon. The tapeworm lives in the lower intestines and competes with the host for nutrients, particularly vitamin B12. Thus, the cases of anaemia (porotic hyperostosis) reported in ancient Chilean and Peruvian skulls could, in certain cases, be related to parasitosis (Arriaza \& Standen 2009). In contrast to the Diphyllobothrium evidence, anisakid paleoparasitological findings (eggs and parasites) are not available. Future studies in zooarchaeological material (fish and other marine mammal remains) and ancient Andean mummies will likely show its presence, especially if advanced molecular biology techniques are applied. Anisakid worms could be present in mummified organs or in archaeological sediments at burials.

The current health conditions have since improved but, paradoxically, despite all the knowledge that we have on parasitic transmission, today's Chilean and Peruvian populations still eat raw fish, consequently exposing themselves to infection by D. pacificum, Anisakis and other parasites. Ceviche is considered both a delicacy and a traditional food in Peru and Chile, such that D. pacificum infection will be difficult to eliminate.

Parasites found in archaeological material have the ability to contribute to the understanding of climate changes in the past. Wildlife helminth studies are an interesting means to understand environmental conditions and climatic changes through time. Combining paleoparasitological studies with modern data, a framework of parasitism evolution can be achieved (Araujo et al. 1993).

During pre-Columbian times, eating raw or poorly cooked marine products must have been common (Reinhard \& Urban 2003). The tradition of eating raw fish increased the overall risk of becoming infected with both D. pacificum and Anisakis. In addition, wood for cooking along the Atacama Desert shores was scarce making long hours of cooking improbable.

D. pacificum is endemic and has affected people of this region as early as $6000 \mathrm{BP}$. Thus, one could have predicted that $D$. pacificum affected all coastal prehistoric populations of this region who were exposed to the ENSO phenomenon. Perhaps even earlier populations such as the Acha (9000 BP) were also affected by D. pacificum considering they also have evidence of a maritime subsistence. Fish are the most important intermediate host involved in these infections, thus zooarchaeological material and sediments have to be analysed in search for D. pacificum and Anisakis.

Finally, this work proposes that parasite archaeological records will vary throughout time according to environmental changes caused by the natural El Niño and $L a$ Niña phenomena. D. pacificum and Anisakis will alternate in prevalence of infections depending on whether the El Niño or La Niña episodes were taking place. These environmental fluctuations have and will put constraints on the reproductive cycle of parasites and hosts. 


\section{REFERENCES}

Araújo A, Rangel A, Ferreira LF 1993. Climatic change in Northeastern Brazil - paleoparasitological data. Mem Inst Oswaldo Cruz 88: 577-579.

Arriaza B, Standen V 2009. Bioarqueología. Historia biocultural de los antiguos pobladores del extremo norte de Chile, Editorial Universitaria, Santiago, 148 pp.

Atías A, Cattan PE 1976. Primer caso humano de infección por Diphyllobothrium pacificum en Chile. Rev Med Chile 104: 216-217.

Aufderheide A, Allison M 1992. Chemical dietary reconstruction of North Chile prehistoric populations by trace mineral analysis. Department of Pathology, University of Minnesota, Duluth. Proceedings of the I World Congress on Mummy Studies 2: 451-461.

Baer JG 1969. Diphyllobothrium pacificum, a tapeworm from sea lions endemic in man along the coastal area of Peru. $J$ Fish Res Board Can 26: 717-723.

Bathurs R 2004. Archaeological evidence of intestinal parasites from coastal shell middens. J Archaeol Sci 32: 115-123.

Bouchet F, Bentrad S, Martin C 2001. Analyse paleoparasitologique. In le quartier Gallo-Romain de la rue de Vernise et sa réoccupation à l'epoque moderne. Archéologie Urbaine. Bull Soc Arch Chameonise 2-3: 148-150.

Bouchet F, Harter S, Le Bailly M 2003. The state of the art of paleoparasitological research in the Old World. Mem Inst Oswaldo Cruz 98: 95-101.

Cabello FC 2007. Aquaculture and public health. The emergence of diphyllobothriasis in Chile and the world. Rev Med Chile 135: 1064-1071.

Cabrera R, Tantaleán M, Rojas R 2001. Diphyllobothrium pacificum (Nybelin, 1931) Margolis, 1956 en Canis familiaris de la ciudad de Chincha, Peru. Bol Chil Parasitol 56: 26-28.

Cabrera R, Trillo-Altamirano M 2004. Anisakidosis: ¿Una zoonosis parasitaria marina desconocida o emergente en el Perú? Rev Gastroenterol Peru 24: 335-342.

Callen EO, Cameron TW 1960. A prehistoric diet revealed in coprolites. New Sci 8: 35-40.

Chai JY, Murrell KD, Lymbery AJ 2005. Fish-borne parasitic zoonoses: status and issues. Int J Parasitol 35: 1233-1254.

Cattan PE, Atias A, Babero BB, Torres D 1977. Helmintofauna de Chile. Pimer hallazgo de Diphyllobothrium pacificum (Nybelin 1931) Margolis 1956, en lobos marinos de la costa chilena. Rev Iber Parasit 37: 3-4.

Cattan PE, Babero BB, Torres D 1976. The helminth fauna of Chile: IV. Nematodes of the genera Anisakis Dujardin, 1845 and Phocanema Myers, 1954 in relation with gastric ulcers in a South American sea lion, Otaria byronia. J Wild Dis 12: 511-515.

Domelier-Espejo S 2001. Contribution à l'etude paléoparasitologique dês sites néolithiques en environnement lacustre dans lês domaines Jurassien et Peri-Alpin, PhD Thesis, UFR de Sciences Exactes et Naturelles, Université de Reims Champagne-Ardenne, $248 \mathrm{pp}$.

Dupouy-Camet J, Peduzzi R 2004. Current situation of human diphyllobothriasis in Europe. Euro Surveil 9: 31-34.

Ferreira LF, Araújo A, Confalonieri U, Nuñez L 1984. The finding of eggs of Diphyllobothrium in human coprolites (4100-1950 BC) from Northern Chile. Mem Inst Oswaldo Cruz 79: 175-180.

Fontugne M, Usselmann P, Lavallée D, Julien M, Hatté C 1999. El Niño variability in the coastal desert of Southern Peru during the Mid-Holocene. Quat Res 52: 171-179.
Geyh MA, Grosjean M, Nuñez L, Schotterer U 1999. Radiocarbon reservoir effect and the timing of the Late-Glacial/Early Holocene humid phase in the Atacama Desert (Northern Chile). Quat Res 52: 143-153.

González A, Sagua H, Cortés L, Lobo J, Neira I, Araya J 1999. Difilobotriasis humana por Diphyllobothrium pacificum. Un nuevo caso en Antofagasta, Norte de Chile. Rev Med Chile 127: $75-77$.

González MT, Poulin R 2005. Nested patterns in parasite component communities of a marine fish along its latitudinal range on the Pacific coast of South America. Parasitology 131: 569-577.

Grosjean M 1994. Paleohydrology of the Laguna Lejía (North Chilean Altiplano) and climatic implications for late-glacial times. Palaeogeogr Palaeoclimatol Palaeoecol 109: 89-100.

Holiday D, Guillen S, Richardson D 2003. Diphyllobothriasis of the Chiribaya Culture (700-1476 AD) of Southern Peru. Comp Parasitol 70: 167-171.

Janicki C 1917. Observations su quelques espèces de poissons afin d'arriver à connaître plus à fond le contenu de leour estomac et pour trover des stades encore inconnus de plerocercoide. Bull Soc Neuch Sci Nat 42: 22-29.

Jansen J Jr, Over HJ 1962. The occurrence of parasites in protohistorical material from North-west Germany. Tijdschr Diergeneesk 87: $1377-1379$.

Kruse H, Kirkemo AM, Handeland K 2004. Wildlife as source of zoonotic infections. Emerg Infect Dis 10: 2067-2072.

Lal S, Steinhart AH 2007. Diphyllobothrium latum: a case of an incidental finding. World J Gastroenterol 13: 1875-1876.

Llagostera A 1992. Early occupations and the emergence of fishermen on the Pacific coast of South America. Anden Past 3: 87-109.

Madl P 2000. The El-Niño (ENSO) phenomenon. Environmental Physics/Letter VO 437-503.

Martinson E, Reinhard K, Buikstra J, Dittmar K 2003. Pathoecology of Chiribaya parasitism. Mem Inst Oswaldo Cruz 98: 195-205.

Meyer M 1970. Cestode zoonoses of aquatic animals. $J$ Wildl Dis 6: 249-254.

Myers BJ 1976. Research then and now on the Anisakidae nematodes. Trans Am Microsc Soc 95: 137-142.

Noh JH, Kim B-J, Kim SM, Ock M-S, Park MI, Goo JY 2003. A case of acute gastric anisakiasis provoking severe clinical problems by multiple infections. Korean J Parasitol 41: 97-100.

Oshima T 1972. Anisakis and anisakiasis in Japan and adjacent areas. Prog Med Parasitol Jpn 4: 305-393.

Patruco R, Tello R, Bonavia D 1983. Parasitological studies of coprolites of pre-hispanic Peruvian populations. Curr Anthropol 24: 393-394.

Reinhard KJ, Aufderheide AC 1990. Diphyllobothriasis in prehistoric Chile and Peru: adaptive radiation of a helminth species to native American populations. Paleopathol News 72: 18-19.

Reinhard K, Urban O 2003. Diagnosing ancient diphyllobothriasis from Chinchorro mummies. Mem Inst Oswaldo Cruz 98: 191-193.

Sagua H, Neira I, Araya J, González J 2001. New cases of Diphyllobothrium pacificum (Nybelin, 1931) Margolis, 1956 human infection in North of Chile, probably related with El Niño phenomenon, 1975-2000. Bol Chil Parasitol 56: 22-25.

Sakanari J, Mckerrow J 1989. Anisakiasis. Clin Microbiol Rev 2: $278-284$. 
Sandweiss D, Maasch K, Burger R, Richardson J, Rollins H, Clement A 2001. Variation in Holocene El Niño frequencies: climate records and cultural consequences in ancient Peru. Geology 29: 603-606.

Santoro CM, Standen VG, Arriaza BT, Marquet PA 2005. Hunter gatherers on the coast and hinterland of the Atacama Desert 17$278^{\circ}$ south latitude. In M Smith, P Hesse (eds,), $23^{\circ}$ south: the archaeology and environmental history of the southern desert, National Museum of Australia, Canberra, p. 172-185.

Schiappacasse V, Niemeyer H 1984. Descripción y análisis interpretativo de un sitio arcaico temprano en la Quebrada de Camarones, Santiago, Chile, Museo Nacional de Historia Natural, Santiago, $41 \mathrm{pp}$.

Semenas L, Kreiter A, Urbanski J 2001. New cases of human diphyllobothriosis in Patagonia, Argentine. Rev Saude Publica 35: 214-216.
Semenas L, Úbeda C 1997. Difilobotriasis humana en la Patagonia, Argentina. Rev Saude Publica 31: 302-307.

Tapia P, Fritz S, Baker P, Seltzer G, Dunbar R 2003. A late quaternary diatom record of tropical climatic history from Lake Titicaca (Peru and Bolivia). Palaeogeogr Palaeoclimatol Palaeoecol 194: 139-164.

Torres P, Moya R, Lamilla J 2000. Nematodos anisákidos de interés en salud pública en peces comercializados en Valdivia, Chile. Arch Med Vet 32: 107-113.

Von Bonsdorff G 1977. Diphyllobothriasis in man, Academic Press, London, $189 \mathrm{pp}$.

West D, Lefèvre C, Corbett D, Crockford S 2003. A burial cave in the western Aleutian Islands, Alaska. Arctic Anthropol 40: 70-86.

Yoon SW, Yu JS, Park MS, Shim JY, Kim HJ, Kim KW 2004. CT findings of surgically verified acute invasive small bowel anisakiasis resulting in small bowel obstruction. Yonsei Med J 45: 739-742. 